\title{
Perubahan Morfofisiologi Bibit Manggis (Garcinia mangostana L.) terhadap Pemberian Polietilena Glikol (PEG)
}

\author{
Morphophysiological Changes of Mangosteen Seedling (Garcinia mangostana L.) on \\ Polyethylene Glycol (PEG) Application
}

\author{
Dhika Prita Hapsari ${ }^{1}$, Roedhy Poerwanto ${ }^{2 *}$, Didy Sopandie ${ }^{2}$, Edi Santosa ${ }^{2}$, \\ dan Deden Derajat Matra ${ }^{2}$
}

Diterima 09 April 2019/Disetujui 05 Februari 2020

\begin{abstract}
Mangosteen requires drought condition to induce flowering, however extending drought period might restrict the plant growth. Therefore, the response of mangosteen to drought stress needs to be studied. This research conducted on May to July 2017 using Randomized Block Design with one factor. The experiment comprised of 4 levels of polyethylene glycol (PEG 6000) treatment, i.e., PEG 0\%, PEG 10\% (-0.03 MPa), PEG 15\% (-0.41 MPa) dan PEG $20 \%$ (-0.67 MPa) (m.v $\left.v^{-1}\right)$. The results showed that there is a dryness of the mangosteen leaves given PEG which occured slowly, starting from the edge of the leaves into the center of midrib. Water consumption was fluctuated until the end of experiment, which the highest was $33.33 \mathrm{ml}$ per day in $0 \%$ PEG treated plant, then decreased until 10 ml per day in 20\% PEG treated plant. Proline content increased from the first week to the third week after all PEG treatments. The highest proline content were found in $15 \%$ PEG $\left(22.14\right.$ umol. $\left.\mathrm{g}^{-1}\right)$ and $20 \%$ PEG $\left(23.46\right.$ umol. $\left.^{-1}\right)$ treated plants. Plant dry mass was low under water stress, and more severe stress resulted in more reduction of plant dry mass level. Water stress did not affect the $N$ and $M g$ content significantly, but reduced $P$ content in mangosteen seedling.
\end{abstract}

Keywords: evapotranspiration, nutrient content, proline, water stress

\begin{abstract}
ABSTRAK
Tanaman manggis membutuhkan kondisi kering untuk menginduksi pembungaan, namun kekeringan yang berkepanjangan dapat menyebabkan terhambatnya pertumbuhan manggis sehingga respon bibit manggis terhadap kekeringan perlu dipelajari. Penelitian dilakukan mulai Mei sampai Juli 2017 menggunakan rancangan acak kelompok (RAK) satu faktor. Perlakuan terdiri atas 4 taraf konsentrasi polietilena glikol (PEG 6000), yaitu PEG 0\%, PEG 10\% (setara -0.19 MPa), PEG 15\% (setara $-0.41 \mathrm{MPa}$ ) dan PEG 20\% (setara $-0.67 \mathrm{MPa}$ ) $\mathrm{m} \cdot \mathrm{v}^{-1}$. Hasil percobaan menunjukkan bahwa terjadi kekeringan pada daun manggis yang diberi PEG yang terjadi secara perlahan dimulai dari tepi daun yang menguning tetapi tetap hijau di bagian tengah. Konsumsi air terus berfluktuasi sampai akhir percobaan mencapai $33.33 \mathrm{ml}$ pada tanaman dengan PEG 0\% dan $10 \mathrm{ml}$ pada tanaman dengan PEG 20\%. Peningkatan konsentrasi prolin terjadi dari minggu pertama sampai dengan minggu ketiga setelah perlakuan pada semua tanaman yang diberi PEG, dengan konsentrasi prolin paling tinggi terdapat pada perlakuan PEG 15\% dan PEG 20\% masing-masing mencapai 22.14 dan $23.46 \mu$ mol.g ${ }^{-1}$. Penurunan bobot kering tanaman semakin tinggi seiring dengan tingginya cekaman yang dialami tanaman. Cekaman yang diakibatkan oleh PEG tidak berpengaruh terhadap kandungan $\mathrm{N}$ dan $\mathrm{Mg}$, namun menurunkan kandungan $\mathrm{P}$ pada bibit manggis.
\end{abstract}

Kata kunci: evapotranspirasi, kandungan hara, prolin, cekaman air

${ }^{1}$ Program Studi Agronomi dan Hortikultura, Sekolah Pascasarjana, Institut Pertanian Bogor

J1. Meranti Kampus IPB Darmaga, Bogor 16680, Indonesia

${ }^{2}$ Departemen Agronomi dan Hortikultura, Fakultas Pertanian, Institut Pertanian Bogor

Jl. Meranti Kampus IPB Darmaga, Bogor 16680, Indonesia

E-mail : roedhy8@yahoo.co.id (*penulis korespondensi) 


\section{PENDAHULUAN}

Tanaman manggis adalah salah satu tanaman tahunan yang sangat peka terhadap kekeringan. Pertumbuhan tanaman manggis sangat lambat, baik saat pembibitan maupun setelah ditanam di lahan. Lambatnya pertumbuhan tersebut diduga akibat kurang berkembangnya sistem perakaran dan tidak adanya akar rambut sehingga laju serapan air dan unsur hara menjadi berkurang (Hidayat, 2005). Karakteristik pertumbuhan akar yang lambat dan jumlah akar lateral yang terbatas menyebabkan bibit manggis peka terhadap cekaman kekeringan. Pengaruh cekaman kekeringan pada tanaman manggis terlihat dari terhambatnya pertumbuhan, perubahan morfologi serta aktivitas fisiologis.

Air memiliki fungsi sebagai penyusun utama protoplasma, bahan baku dalam proses fotosintesis dan sebagai pelarut dalam sejumlah proses hidrolisis, sehingga terbatasnya serapan air akan menyebabkan terhambatnya berbagai aktivitas sel (Taiz dan Zeiger, 2012). Defisit air menyebabkan penutupan stomata yang berakibat pada penurunan konsentrasi $\mathrm{CO}_{2}$ seluler dan berujung pada terjadinya ketidakseimbangan energi sehingga konsentrasi reactive oxygene species (ROS) meningkat. Peningkatan kandungan ROS meningkatkan terjadinya proses-proses oksidatif dan kerusakan organ-organ fotosintesis (Sopandie, 2014). Bahkan Harjadi dan Yahya (1988) menyebutkan bahwa stres air yang ringan (sekitar -1 sampai -3 bar) sudah dapat menyebabkan pembelahan dan pembesaran sel menjadi terhambat bahkan berhenti sama sekali.

Masing-masing tanaman memiliki respon, tingkat toleransi dan mekanisme yang berbeda terhadap cekaman kekeringan. Menurut Mustaha (2012) peningkatan taraf cekaman kekeringan pada tanaman manggis menurunkan beberapa aktivitas fisiologi, seperti potensial air daun, laju transpirasi, laju fotosintesis dan daya hantar stomata, sehingga menyebabkan terjadinya perubahan morfologi yang nampak dari penurunan pertumbuhan akar dan penurunan pertumbuhan tajuk. Mekanisme perubahan fisiologis yang terjadi akibat adanya cekaman kekeringan pada tanaman manggis pernah dijelaskan pada penelitian yang dilakukan oleh Mustaha (2012) menggunakan media tanah. Simulasi stress air pada penelitian ini dilakukan pada larutan hara dengan menggunakan polietilena glikol (PEG 6000) yang kesetaraan konsentrasinya dengan potensial air perakaran telah diketahui. Senyawa ini dapat digunakan untuk simulasi kekeringan karena tidak menyebabkan keracunan pada tanaman, namun dapat menyebabkan tanaman mengalami kekurangan air seperti di lapang (Kong et al., 1998). Simulasi kekeringan yang dilakukan menggunakan polietilena glikol (PEG) juga umum digunakan untuk studi perkecambahan biji pada tanaman jagung (Khodarahmpour, 2011), evaluasi penggunaan zat pengatur tumbuh pada pisang (Mahmood et al., 2012), seleksi aksesi sorgum (Bibi et al., 2012) serta respon fisiologi dan biokimia pada tanaman kedelai (Hamayun et al., 2010), kacang bali (Kumar et al., 2011), salicornia (Parida dan Jha, 2013), kenikir (Ghane et al., 2012), gandum (Marcinska, 2012; Sapre dan Vakharia, 2017) pada kondisi tercekam. Penggunaan PEG pada penelitian ini diharapkan dapat menjelaskan pertumbuhan, respon morfofisiologi serta serapan hara bibit manggis pada berbagai tingkat cekaman akibat pemberian PEG dalam waktu yang relatif singkat.

\section{BAHAN DAN METODE}

Percobaan ini dilaksanakan pada bulan Mei sampai Juli 2017 di Laboratorium Pascapanen Departemen Agronomi dan Hortikultura, IPB. Analisis hara dilakukan di Laboratorium Pengujian Departemen Agronomi dan Hortikultura, Institut Pertanian Bogor (IPB), sedangkan analisis prolin dilakukan di Laboratorium Fisiologi dan Biologi Molekuler Tumbuhan Biologi, IPB. Bahan tanam yang digunakan pada penelitian ini adalah bibit manggis asal seedling berumur 2 tahun dari sentra pembibitan Agropromo IPB dengan tinggi $\pm 30 \mathrm{~cm}$ dan jumlah daun sekitar 17-20 helai yang diupayakan seseragam mungkin. Penanaman bibit manggis dilakukan menggunakan gelas ukur yang berisi $\mathrm{AB}$ mix sebagai larutan hara dan dilengkapi dengan aerator yang dipasang 24 jam.

Percobaan dilakukan menggunakan Rancangan Acak Kelompok (RAK) dengan satu faktor, yaitu tingkat cekaman menggunakan polyetilana glikol (PEG) 6000 sebanyak 4 taraf yang diulang sebanyak 3 kali sehingga terdapat 15 satuan percobaan. 
Perlakuan terdiri atas satu faktor, yaitu PEG 6000 dengan konsentrasi $0 \%, 10 \%(-0.19 \mathrm{MPa})$, $15 \%(-0.41 \mathrm{MPa})$ dan $20 \%(-0.67 \mathrm{MPa}) \mathrm{m} / \mathrm{v}$ (Mexal et al., 1975). Bibit manggis dibongkar dari polibag dan akarnya dibersihkan menggunakan air. Bibit dipindahkan ke dalam gelas ukur yang telah berisi larutan hara $\mathrm{AB}$ Mix dan dilengkapi dengan aerator. PEG diberikan ke dalam larutan hara 3 hari setelah pindah tanam. Konsentrasi PEG 10\% dibuat dengan cara melarutkan 100 g kristal PEG dengan aquades sampai mencapai volume satu liter. Begitu selanjutnya pada konsentrasi 15 dan 20\%, masing-masing sebanyak 150 dan $200 \mathrm{~g}$ kristal PEG dilarutkan dalam satu liter air aquades. Larutan hara diganti setiap seminggu sekali untuk menjaga $\mathrm{pH}$ dan kandungan hara tetap konstan.

\section{Pengamatan Morfologi}

Pengamatan morfologi yang dilakukan pada percobaan ini meliputi: 1) perubahan kondisi daun manggis yang mengalami kekeringan dengan cara mengamati pola kekeringan pada daun manggis secara visual dan mengambil gambar daun tersebut dengan kamera, 2) sudut daun yang diukur setiap 2 hari sekali dari awal hingga akhir percobaan menggunakan busur derajat, dimana sudut daun yang diukur adalah sudut antara sepasang daun pertama seperti pada Gambar 1.

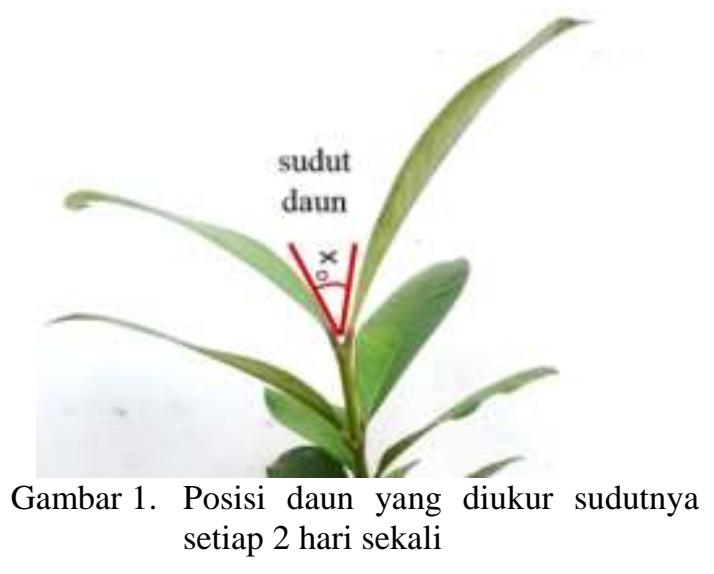

\section{Pengamatan Fisiologi}

Pengamatan fisiologi yang dilakukan pada percobaan ini meliputi: 1) konsumsi air tanaman yang diukur setiap hari dengan cara mencatat penurunan air dari hari sebelumnya pada gelas ukur, 2) pengukuran bobot kering yang dilakukan pada akhir percobaan dengan cara mengoven sampel pada suhu $80{ }^{\circ} \mathrm{C}$ selama 72 jam kemudian ditimbang menggunakan timbangan digital, 3) kandungan hara makro seluruh daun manggis yang dianalisis pada akhir percobaan di Laboratorium Pengujian Departemen Agronomi dan Hortikultura, IPB, serta 4) konsentrasi prolin pada seluruh daun bibit manggis yang dilakukan pada minggu ke1, 2 dan 3 berdasarkan metode Bates et al. (1973) sebagai berikut. Daun manggis sebanyak $0.4 \mathrm{~g}$ digerus dan dihomogenisasi dalam $10 \mathrm{ml}$ larutan asam sulfosalisilat 3\% kemudian disentrifugasi pada kecepatan 10.000 rpm selama 10 menit. Selanjutnya, $2 \mathrm{ml}$ supernatan daun direaksikan dengan $2 \mathrm{ml}$ asam ninhidrin dan $2 \mathrm{ml}$ asam asetat glasial dalam tabung falcon $15 \mathrm{ml}$ selama 1 jam pada temperatur $80^{\circ} \mathrm{C}$, kemudian direndam dalam air es. Filtrat diekstraksi dengan $4 \mathrm{ml}$ toluena, lalu dikocok dengan vorteks. Absorban diukur dengan spektrofotometer pada panjang gelombang $520 \mathrm{~nm}$. Konsentrasi prolin $\left(\mathrm{mmol} . \mathrm{g}^{-1}\right)$ ditentukan dari kurva standar prolin dan dihitung terhadap bobot segar.

\section{Analisis Data}

Data kuantitatif dianalisis menggunakan analisis ragam (Uji F) serta pengujian lanjut dilakukan dengan menggunakan Duncan multiple range test (DMRT) pada taraf 5\%. Perangkat lunak yang digunakan adalah software Statistical Analysis System 9.4 (SAS 9.4 M4).

\section{HASIL DAN PEMBAHASAN}

\section{Respon Morfologi}

Perubahan morfologi daun manggis ditunjukkan pada Gambar 2. Pada akhir percobaan (hari ke-21) daun manggis yang diberikan PEG mengering secara bertahap, dimulai dari tepi daun yang menguning, sementara bagian tengah daun masih segar dan berwarna hijau. Berdasarkan penampakan morfologinya, tingkat kekeringan semakin parah seiring dengan meningkatnya konsentrasi PEG yang diberikan, yaitu PEG 10\%, PEG 15\% dan PEG 20\%. 

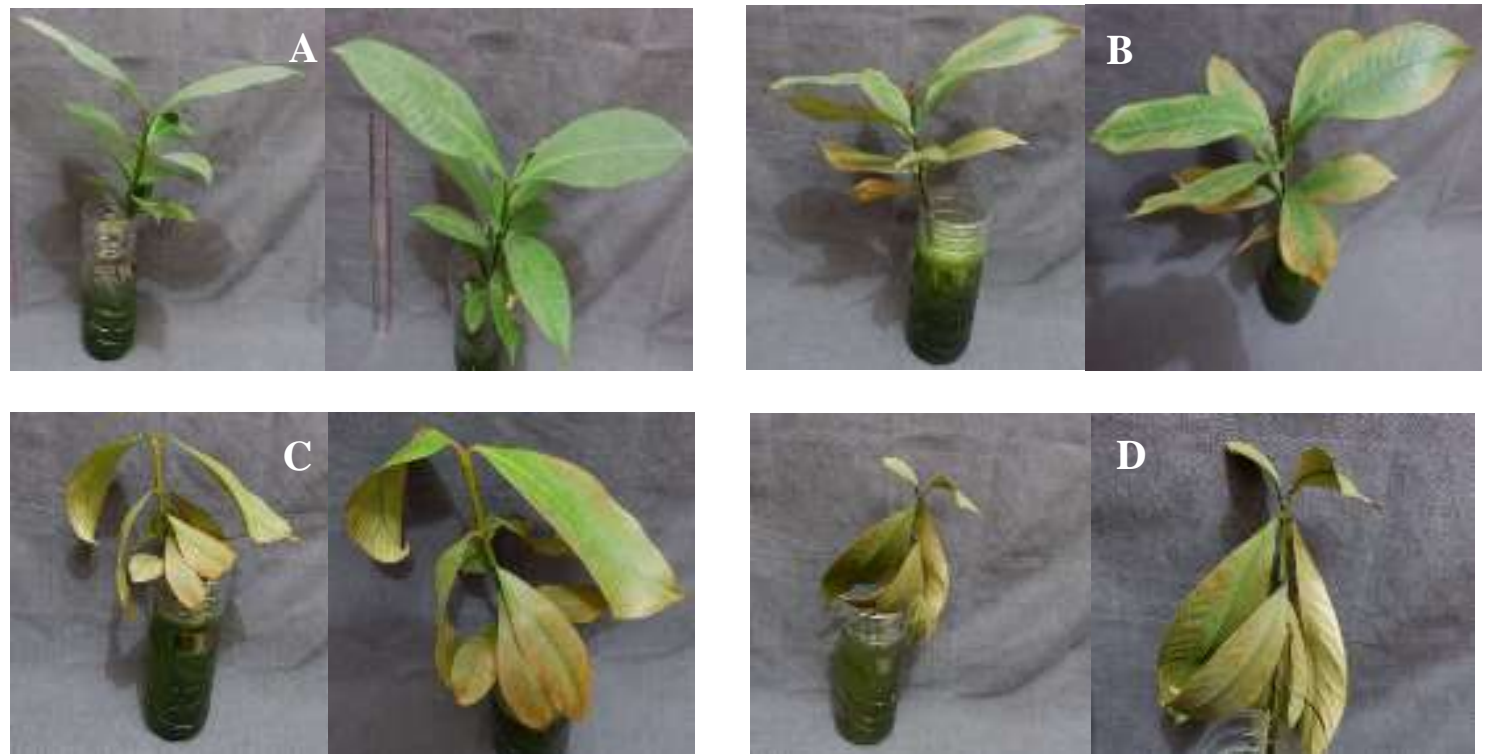

Gambar 2. Respon morfologi daun bibit manggis 3 minggu setelah perlakuan PEG, yaitu A) PEG 0\% B) PEG 10\% C) PEG 15\% dan D) PEG 20\%.

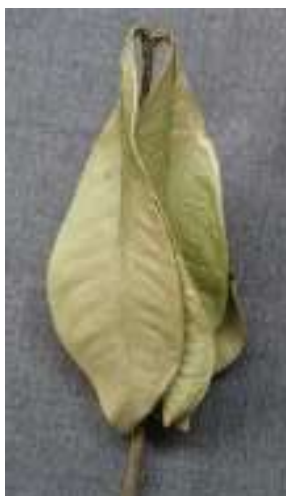

Gambar 3. Penampakan visual daun bibit manggis 3 minggu setelah tidak diberi media tumbuh

Proses kekeringan daun karena cekaman akibat pemberian PEG ini berbeda dengan kekeringan pada daun manggis yang diakibatkan oleh pencabutan bibit manggis dari media tumbuhnya. Gejala kekeringan pada bibit manggis yang tidak diberi media tumbuh apapun terjadi secara menyeluruh sehingga tidak terdapat pola kekeringan seperti pada bibit yang diberi PEG (Gambar 2). Tanaman biasanya membatasi jumlah daunnya sebagai respon terhadap kondisi cekaman untuk memperkecil luas permukaan daun sehingga transpirasi menurun (Patanè, 2010) dan kebutuhan air berkurang (Jaleel et al., 2009). Kekeringan daun secara bertahap pada bibit manggis yang mengalami cekaman akibat PEG terjadi karena proses degradasi klorofil. Christ et al. (2014) melaporkan bahwa proses degradasi klorofil ditunjukkan oleh peningkatan enzim pendegradasi klorofil, pheophorbide-a-oxygenase (PAO). Selain itu kekeringan pada daun juga diduga akibat adanya degradasi asimilat dari daun sebagai source ke bagian sink lain dalam upaya efisiensi proses remobilisasi nutrisi (Lee et al., 2008). Laju transpor sukrosa dari source menuju sink bergantung pada laju fotosintesis dan konsentrasi sukrosa yang ada pada daun. Farooq et al. (2009) menyimpulkan bahwa cekaman tidak hanya membatasi kapasitas source dan sink, tetapi proses phloem loading, translokasi asimilat dan pembagian bahan kering juga terganggu. Efek yang terjadi tersebut sangat bervariasi bergantung pada spesies tanaman, stadia pertumbuhan, durasi dan keparahan cekaman.

\section{Respon Fisiologi}

Konsumsi air pada percobaan ini menunjukkan kemampuan tanaman dalam menyerap air. Terjadi fluktuasi konsumsi air pada berbagai konsentrasi PEG, namun dapat dilihat bahwa konsumsi air paling tinggi terdapat pada perlakuan PEG 0\% (Gambar 4). Hal tersebut menunjukkan bahwa tanpa pemberian PEG, tanaman tidak mengalami stres dehidrasi dan dapat bermetabolisme secara normal. Pada hari pertama pemberian PEG, konsumsi air antar perlakuan tidak berbeda nyata, yaitu berkisar antara 20-30 ml. 
Penurunan konsumsi air pada tanaman yang diberi PEG sudah mulai terlihat pada hari kedua, dimana terjadi perbedaan yang sangat signifikan antara tanaman yang tidak diberi PEG dengan tanaman yang diberi PEG, yaitu dengan selisih lebih dari 50\%. Konsumsi air terus berfluktuasi sampai akhir percobaan. Pada akhir percobaan tanaman yang tidak diberi PEG mengosumsi air sebesar $33.33 \mathrm{ml}$ per hari, sedangkan pada tanaman yang diberi PEG konsumsi airnya hanya berkisar $8-10 \mathrm{ml}$ tanaman ${ }^{-1}$ per hari. Polyethylene glycol (PEG) merupakan bahan kimia yang paling representatif untuk melakukan simulasi kekeringan pada tanaman, dimana PEG dapat menjadikan kondisi larutan hara sama seperti tanah media tumbuh tanaman yang mengalami kekeringan (Verslues dan Bray, 2004; van der Weele et al., 2000). Stres kekeringan ataupun dehidrasi pada tanaman terjadi ketika terdapat penurunan ketersediaan air tanah, dimana dalam percobaan ini penurunan ketersediaan air terjadi akibat PEG. Penurunan ketersediaan air tanah ini juga diartikan sebagai penurunan potensial air tanah (Kramer dan Boyer,1995). Penurunan potensial air pada media tumbuh membuat tanaman sulit mengambil air, sebagai akibatnya tanaman merespon dengan cara menghindari terjadinya kehilangan air, salah satunya dengan mengurangi aktivitas transpirasi. Rouphael et al. (2012) menyatakan bahwa ketika tanah kering, serapan air oleh akar tanaman tidak dapat memenuhi laju transpirasi yang tinggi. Air yang hilang dari daun melalui proses transpirasi lebih besar dari total air yang diserap tanaman sehingga menyebabkan daun pada tanaman manggis yang mengalami stress akibat pemberian PEG menjadi layu.

Terjadi peningkatan konsentrasi prolin dari minggu pertama sampai dengan minggu ketiga setelah perlakuan pada semua tanaman yang diberi PEG (Gambar 5). Peningkatan konsentrasi prolin paling tinggi terdapat pada perlakuan PEG 15\% dan PEG 20\% dengan konsentrasi prolin masing-masing mencapai 22.14 dan 23.46 umol.g ${ }^{-1}$ pada minggu ketiga setelah perlakuan. Konsentrasi prolin tersebut nyata lebih tinggi dibandingkan dengan konsentrasi prolin pada perlakuan PEG 0\%, yaitu hanya sebesar 7 umol.g $^{-1}$ pada minggu ketiga setelah perlakuan.

Tanaman memiliki kemampuan bertahan pada kondisi tercekam dengan cara menjaga tekanan turgor sel melalui penurunan potensial air dengan mengakumulasi solut seperti asam amino prolin, atau yang biasa disebut sebagai osmoregulator (Sopandie, 2014; Ranganayakulu et al., 2013; Wani et al., 2013). Kandungan prolin yang tinggi juga menunjukkan bahwa tanaman berada pada kondisi tercekam, namun cenderung toleran pada kondisi tersebut. Beberapa tanaman yang toleran terhadap cekaman, baik kekeringan maupun salin, menunjukkan kandungan prolin yang lebih tinggi dibandingkan dengan tanaman yang peka (Misra dan Gupta, 2005; Ashraf dan Foolad, 2007; Celik dan Atak, 2012). Tanaman manggis tergolong tanaman yang moderat dalam menanggapi cekaman. Hapsari (2018) melaporkan bahwa respon bibit manggis terhadap stres air tergolong lambat, dimana bibit manggis baru menunjukkan gejala pada minggu ke-3 setelah perlakuan cekaman kekeringan. Tanaman manggis pada penelitian ini berusaha membentuk prolin untuk menjaga tekanan osmotiknya, namun kandungan prolin yang tinggi pada minggu ketiga tidak dapat lagi membantu tanaman untuk bertahan hidup akibat tingkat stres yang semakin parah. Tanpa adanya prolin, proses tercekamnya tanaman menuju kematian akan semakin cepat.

\section{Produksi Bobot Kering}

Cekaman kekeringan pada bibit manggis menyebabkan penurunan bobot kering (Gambar 5). Bobot kering paling rendah terdapat pada perlakuan PEG 20\% dengan nilai bobot kering sebesar $9.37 \mathrm{~g}$. Tanaman dengan perlakuan PEG 0\% memiliki bobot kering sebesar $14.62 \mathrm{~g}$ yang sangat nyata lebih tinggi dibandingkan dengan tanaman lainnya. Pada perlakuan PEG 20\%, tanaman diduga tidak mengalami penambahan bobot kering, sedangkan pada perlakuan lain dengan konsentrasi PEG yang lebih rendah masih dapat meningkatkan produksi bobot keringnya selama kondisi tercekam. Hal tersebut dapat dilihat dari bibit manggis yang mengalami kekeringan pada hari pertama karena tidak diberi media apa pun (Gambar 2) menunjukkan bobot kering sebesar 9.5 g (data tidak ditampilkan), tidak berbeda nyata dengan bobot kering perlakuan PEG 20\% pada minggu ketiga setelah perlakuan.

Hal tersebut terjadi diduga akibat tingginya $\mathrm{ABA}$ akibat cekaman yang dialami tanaman. Zhang et al. (2017) menyatakan 
bahwa bobot kering memiliki korelasi negatif yang signifikan dengan $\mathrm{ABA}$, yang mana $\mathrm{ABA}$ juga memiliki korelasi negatif dengan kandungan air pada daun (relative water content). Penambahan bobot kering sangat berkaitan erat dengan proses pertumbuhan dan pemanjangan sel tanaman. Pertumbuhan sel dianggap sebagai salah satu proses fisiologis tanaman yang sensitif terhadap stres air akibat terjadinya penurunan tekanan turgor (Anjum $e t$ al. 2011). Pemanjangan sel pada kondisi stres air yang parah dapat terhambat akibat gangguan aliran air dari xilem menuju titik-titik pemanjangan sel. Selain itu, stres air juga menyebabkan gangguan mitosis yang berujung pada penurunan pertumbuhan dan faktor produksi tanaman lainnya (Hussain et al. 2008).
Pertumbuhan sel yang terhambat ini menyebabkan rendahnya bobot kering pada tanaman yang mengalami cekaman.

Terbatasnya cadangan air tanaman menyebabkan penurunan laju fotosintesis sehingga fotosintat yang terbentuk juga berkurang. Penurunan bobot kering tanaman akibat adanya cekaman kekeringan salah satunya disebabkan oleh terbatasnya fotosintat yang terbentuk (Du et al., 2010; Farooq et al., 2009). Terbatasnya fotosintat yang terbentuk pada tanaman manggis ditunjukkan pada Gambar 3, yang mana penampakan visual daun manggis pada perlakuan PEG sudah tidak optimal untuk melakukan proses fotosintesis dibandingkan dengan perlakuan kontrol.

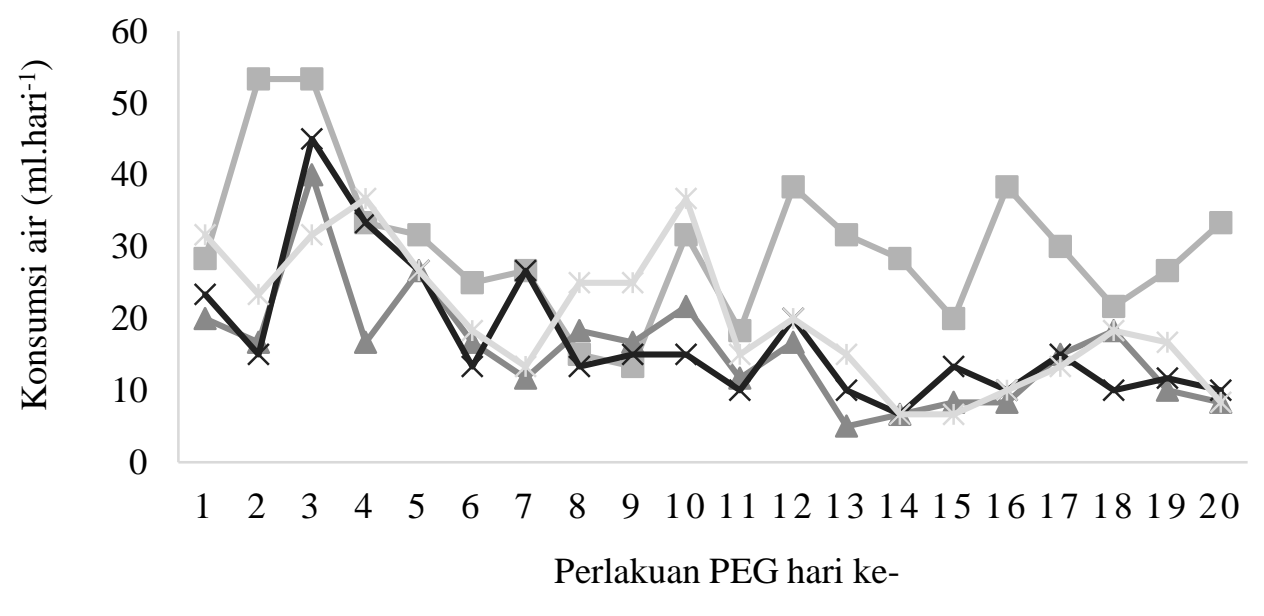

Gambar 4. Konsumsi air bibit manggis pada berbagai konsentrasi PEG pada hari ke-1 s.d hari ke-20 setelah perlakuan.

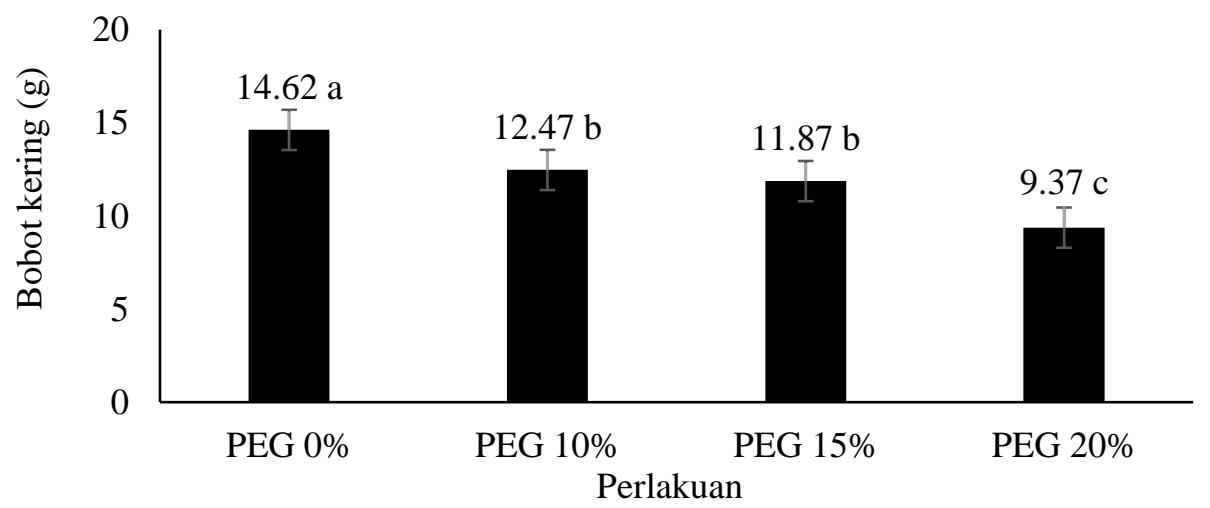

Gambar 5. Bobot kering total bibit manggis pada berbagai perlakuan di akhir percobaan (hari ke-21). Huruf yang berbeda antar perlakuan menunjukkan pengaruh yang berbeda nyata pada taraf $5 \%$. 


\section{Kandungan Hara Makro}

Kandungan hara bibit manggis pada berbagai tingkat cekaman kekeringan akibat pemberian PEG ditunjukkan pada Tabel 1. Dapat dilihat bahwa kandungan $\mathrm{N}$ dan Mg tidak berbeda nyata antar semua perlakuan. Kandungan $\mathrm{P}$ pada tanaman yang tidak diberi PEG nyata lebih tinggi dibandingkan dengan perlakuan lainnya. Tanaman yang diberi PEG $20 \%$ memliki kandungan $\mathrm{Ca}$ yang nyata lebih tinggi dibandingkan dengan tanaman yang tidak diberi PEG, namun tidak berbeda nyata dengan perlakuan lainnya. Kondisi yang sedikit berbeda terdapat pada kandungan $\mathrm{K}$ pada bibit manggis, dimana kandungan $\mathrm{K}$ paling rendah terdapat pada tanaman yang diberi PEG $10 \%$, namun tidak berbeda nyata dengan tanaman kontrol. Tanaman yang diberi 15\% dan 20\% PEG memiliki kandungan $\mathrm{K}$ yang nyata lebih tinggi dibandingkan dengan tanaman yang diberi $10 \%$ PEG, namun tidak berbeda nyata dengan tanaman kontrol. Kandungan $\mathrm{K}$ yang lebih tinggi pada tanaman yang tercekam juga dilaporkan pada tanaman barley (Wu et al., 2014). Kondisi tercekam menyebabkan peningkatan ROS, khususnya pada jaringan mesofil, sehingga terjadi peningkatan kandungan $\mathrm{K}$ untuk menekan ROS pada tanaman toleran (Cakmak, 2005). Peningkatan kandungan $\mathrm{K}$ juga terjadi pada beberapa tanaman yang mengalami cekaman (Morgan et al., 2014). Peningkatan kandungan K dari penggunaan PEG 10\% ke PEG 15\% dan 20\% diduga ada hubungannya dengan perannya dalam menjaga turgor tanaman dan proses menutup dan membukanya stomata. Unsur $\mathrm{K}^{+}$ dan $\mathrm{Mg}^{+}$berperan dalam mengurangi potensial osmotik pada tanaman sehingga dapat mentriger tekanan turgor tanaman untuk melakukan transport berbagai macam solut yang ada di xilem serta mengatur keseimbangan air tanaman (Jin et al., 2016).

Tanaman padi yang tercekaman kekeringan mengalami peningkatan kandungan $\mathrm{Ca}$ dan $\mathrm{Mg}$ (Chen et al., 2011), sementara terjadi penurunan serapan hara $\mathrm{N}, \mathrm{P}$, dan $\mathrm{K}$ pada tanaman gandum yang tercekam (Nawaz et al., 2012). Wu et al. (2007) melaporkan bahwa pada spesies Sophora davidii terjadi respon terhadap serapan $\mathrm{N}$ yang tidak konsisten pada kondisi cekaman kekeringan. Hapsari et al. (2018) melaporkan bahwa terjadi peningkatan kandungan $\mathrm{Ca}$ pada bibit manggis yang mengalami cekaman kekeringan lebih tinggi, dimana peningkatan tersebut utamanya terjadi pada Ca-pektat dan Ca terlarut yang memiliki peran masing-masing sebagai komponen penyusun dinding sel (Peaucelle et al., 2012) dan transduksi sinyal di sitoplasma (Kader dan Lindberg, 2010). Waraich et al. (2011) menyatakan bahwa tanaman yang toleran terhadap cekaman memiliki mekanisme untuk meningkatkan penyerapan, transpor serta akumulasi hara, terutama hara yang berperan sebagai osmoregulator.

Tabel 1. Konsentrasi prolin daun manggis pada berbagai konsentrasi PEG minggu ke-1 s.d minggu ke-3

\begin{tabular}{lccc}
\hline \multirow{2}{*}{ Konsentrasi PEG } & \multicolumn{3}{c}{ Konsentrasi prolin minggu ke- } \\
\cline { 2 - 4 } & 1 & 2 & 3 \\
\hline PEG 0\% & $1.66 \mathrm{~b}$ & $6.14 \mathrm{~b}$ & $7.76 \mathrm{c}$ \\
PEG 10\% & $4.29 \mathrm{a}$ & $13.32 \mathrm{a}$ & $15.27 \mathrm{~b}$ \\
PEG 15\% & $4.81 \mathrm{a}$ & $15.71 \mathrm{a}$ & $22.14 \mathrm{a}$ \\
PEG 20\% & $5.31 \mathrm{a}$ & $16.61 \mathrm{a}$ & $23.46 \mathrm{a}$ \\
\hline Uji F & $*$ & $*$ & $*$ \\
\hline
\end{tabular}

Tabel 2. Kandungan hara makro bibit manggis pada berbagai perlakuan di akhir percobaan (minggu ke-3)

\begin{tabular}{lccccc}
\hline Perlakuan & $\mathrm{N}(\%)$ & $\mathrm{P}(\%)$ & $\mathrm{K}(\%)$ & $\mathrm{Ca}(\%)$ & $\mathrm{Mg}(\%)$ \\
\hline Tanpa PEG & 1.517 & $0.447 \mathrm{a}$ & $1.597 \mathrm{ab}$ & $0.797 \mathrm{~b}$ & 0.170 \\
PEG 10\% & 1.520 & $0.087 \mathrm{~b}$ & $1.350 \mathrm{~b}$ & $0.837 \mathrm{ab}$ & 0.197 \\
PEG 15\% & 1.490 & $0.087 \mathrm{~b}$ & $1.730 \mathrm{a}$ & $0.887 \mathrm{ab}$ & 0.180 \\
PEG 20\% & 1.537 & $0.077 \mathrm{~b}$ & $1.767 \mathrm{a}$ & $0.960 \mathrm{a}$ & 0.187 \\
\hline Uji F & tn & $*$ & $*$ & $*$ & tn
\end{tabular}

Keterangan : Angka-angka yang diikuti huruf yang sama pada kolom yang sama menunjukkan nilai yang tidak berbeda nyata berdasarkan uji lanjut DMRT pada taraf $5 \%$. 


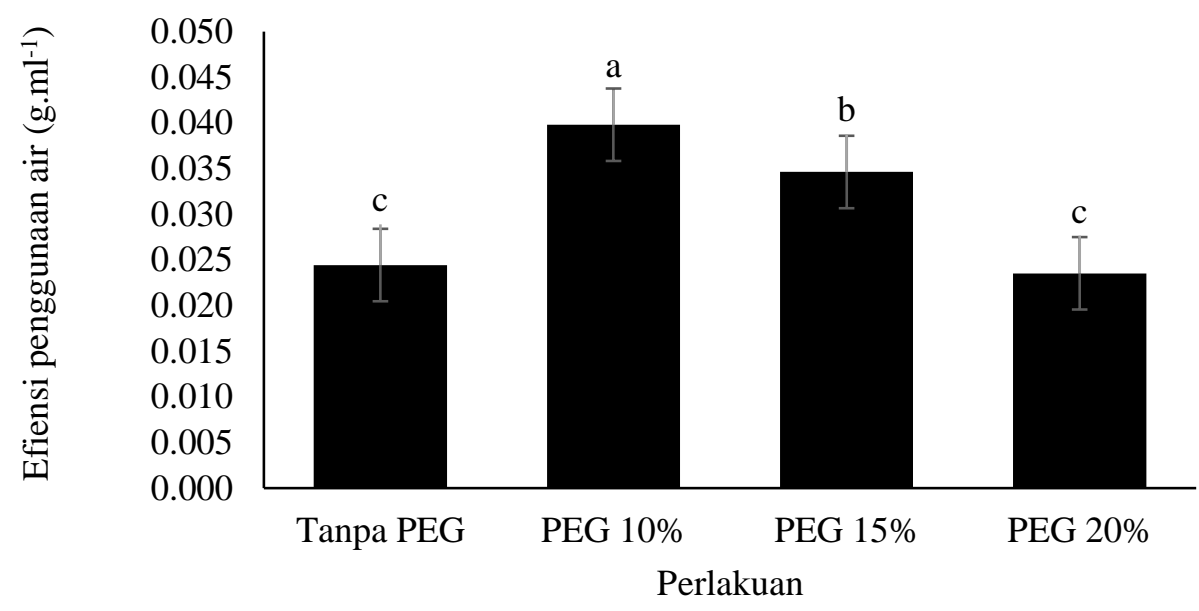

Gambar 6. Efisiensi penggunaan air bibit manggis pada berbagai konsentrasi PEG

Menurut Miransari (2010) kondisi tanaman yang tercekam akan menghambat pertumbuhan akar yang berakibat pada penurunan serapan hara yang kurang mobil seperti fosfor. Di sisi lain, kandungan hara immobil seperti Ca menunjukkan peningkatan pada kondisi tercekam. Hal tersebut diduga ada hubungannya dengan peran $\mathrm{Ca}$ sebagai second messenger. Fahad et al. (2017) menambahkan bahwa hubungan antara hara dan tanaman cukup rumit, terutama kaitannya pada proses fisiologi tanaman sehingga membutuhkan penelitian yang lebih terperinci pada tingkat molekuler yang lebih detail dan mendalam.

\section{Efisiensi Penggunaan Air}

Gambar 6 menunjukkan efisiensi penggunaan air bibit manggis pada beberapa konsentrasi PEG. Efisiensi penggunaan air menunjukkan jumlah air yang dapat digunakan tanaman untuk memproduksi bobot kering (Ali et al., 2005). Cekaman yang terjadi pada bibit manggis akibat PEG $10 \%$ dan $15 \%$ menyebabkan peningkatan efisiensi penggunaan air masing-masing sebesar $66 \%$ dan 45\%, sedangkan penggunaan PEG 20\% memiliki efisiensi penggunaan air yang nyata lebih rendah dibandingkan dengan PEG $10 \%$ dan $15 \%$ namun tidak berbeda nyata dengan tanaman yang tidak diberi PEG. Hal tersebut menunjukkan bahwa cekaman yang terjadi pada tanaman yang diberi 20\% PEG, dengan potesial air sebesar $-0.67 \mathrm{MPa}$, merupakan cekaman kekeringan yang cukup tinggi sehingga tanaman tidak mampu menggunakan air yang tersisa untuk memproduksi bobot keringnya. Meningkatnya efisiensi penggunaan air pada bibit manggis yang tercekam akibat pemberian PEG $10 \%$ dan $15 \%$ mengindikasikan bahwa tanaman manggis merupakan tanaman yang moderat toleran terhadap cekaman kekeringan. Peningkatan efisiensi penggunaan air pada kondisi cekaman kekeringan juga terjadi pada tanaman gandum (Fotovat et al., 2007), tapak dara (Jaleel et al., 2008), kacang tanah (Songsri et al., 2009) dan bawang merah (Swasono 2012) yang toleran cekaman kekeringan.

\section{KESIMPULAN}

Simulasi kekeringan dengan
menggunakan PEG menunjukkan pola
kekeringan pada daun manggis, dimana pola
kekeringan semakin menyebar seiring dengan
meningkatnya cekaman. Kandungan prolin
semakin meningkat seiring dengan tingginya
konsentrasi PEG dan lamanya periode cekaman
yang dialami oleh bibit manggis. Pemberian
PEG konsentrasi rendah meningkatkan
efisiensi penggunaan air tanaman. Hambatan
serapan hara hanya terlihat signifikan pada
unsur P pada tanaman yang tercekam,
sementara tidak ada perbedaan kandungan hara
$\mathrm{N}$ dan Mg pada tanaman normal dan tercekam.
Dapat direkomendasikan bahwa untuk
mendapatkan bibit manggis yang baik dan tidak
tercekam, potensial air tanah pada bibit
manggis sebaiknya berada di atas nilai -0.41


MPa. Penelitian lebih lanjut terkait kalibrasi dan optimasi potensial air tanah (dengan satuan $\mathrm{MPa}$ ) ke kebutuhan air tanaman (frekuensi penyiraman) masih diperlukan untuk memudahkan pemahaman petani sebagai implementasi lebih lanjut.

\section{UCAPAN TERIMA KASIH}

Terima kasih penulis ucapkan kepada Kementerian Riset, Teknologi dan Pendidikan Tinggi yang telah membiayai penelitian ini melalui program PMDSU Batch 2.

\section{DAFTAR PUSTAKA}

Ali, M., C. R. Jensen, V. O. Mongensen, M. N. Andersen, I. E. Henson. 2005. Root signalling and osmotic adjustment during intermittent soil drying sustain grain yield of field grown wheat. Field Crops Research. 62:35-52.

Anjum, S.A., X.Y. Xie, L. C. Wang, M. F. Saleem, C. Man, W. Lei. 2011. Morphological, physiological and biochemical responses of plants to drought stress. Afr J Agric Res. 6: 20262032.

Ashraf, M., M. R. Foolad. 2007. Roles of glycine betaine and proline in improving plant abiotic stress resistance. Environ Exp Bot. 59: 206-216.

Bates, L.S. 1973. Rapid determination of free proline for water-stress studies. Plant and Soil. 39: 205-207.

Bibi, A., H. A. Sadaqat, M. H. N. Tahir, H. M. Akram. 2012. Screening of sorghum (Sorghum bicolor Var Moench) for drought tolerance at seedling stage in polyethylene glycol. J. Anim. Plant Sci. 22(3): 671-678.

Cakmak, I. 2005. The role of potassium in alleviating detrimental effects of abiotic stresses in plants. Journal of Plant Nutrition and Soil Science. 168: 521-530.
Celik, O., C. Atak. 2012. The effect of salt stress on antioxidative enzymes and proline content of two Turkish tobacco varieties. Turk J. Biol. 36: 339-356.

Chen, W., X. Yao, K. Cai, J. Chen. 2011. Silicon alleviates drought stress of rice plants by improving plant water status, photosynthesis and mineral nutrient absorption. Boil. Trace Elem. Res. 142: 67-76.

Christ, B., A. Egert, I. Süssenbacher, B. Kräutler, D. Bartels, S. Peters, S. Hörtensteiner. 2014. Water deficit induces chlorophyll degradation via the "PAO/phyllobilin" pathway in leaves of homoio- (Craterostigma pumilum) and poikilochlorophyllous (Xerophyta viscosa) resurrection plants. Plant, Cell \& Environment. 37(11): 2521-2531.

Du, N., W. Guo, X. Zhang, R. Wang. 2010. Morphological and physiological responses of Vitex negundo L. var. heterophylla (Franch.) Rehd. to drought stress. Acta Physiologiae Plantarum. 32(5): 839-848.

Fahad, S., A.A. Bajwa, U. Nazir, S.A. Anjum, A. Faroo, A. Zohaib, S. Sadia, W. Nasim, S. Adkins, A. Saud, M.Z. Ihsan, H. Alharby, C. Wu, D. Wang, J. Huang. 2017. Crop production under drought and heat stress: plant responses and management options. Front Plant Sci. 8:1147.

Farooq, M., A. Wahid, N. Kobayashi, D. Fujita, S.M.A. Basra. 2009. Plant drought stress: effects, mechanisms and management. Agron. Sustain. Dev. 29: 185-212.

Fotovat, R., M. Valizadeh, M. Toorchi. 2007. Association between water-use efficiency components and total chlorophyll content (SPAD) in wheat (Triticum aestivum L.) under wellwatered and drought stress conditions. Journal of Food, Agriculture and Environment. 5(3\&4): 225-227. 
Ghane, S. G., V. H. Lokhande, T. D. Nikam. 2011. Differential growth, physiological and biochemical responses of niger (Guizotia abyssinica Cass.) cultivars to water-deficit (drought) stree. Acta Physiologiae Plantarum. 34: 215-225.

Hamayun, M., S. A. Khan, Z. K. Shinwari, A. L. Khan, N. Ahmad, I. Lee. 2010. Effect of polyethylene glycol induced drought stress on physio-hormonal attributesof soybean. Pakistan Journal of Botany. 42(2): 977-987.

Hapsari, D.P., R. Poerwanto, D. Sopandie, E. Santosa, D.D. Matra. 2018. Partial rootzone irrigation effects on growth, metabolism and calcium status of Mangosteen seedling (Garcinia mangostana L.). Adv. Hort. Sci. 32(1): 49-59.

Harjadi, S.S., S. Yahya. 1988. Fisiologi Stres Lingkungan. PAU Bioteknologi. Bogor.

Hidayat, R. 2005. Kajian periode dormansi dan ritme pertumbuhan tunas dan akar tanaman manggis (Garcinia mangostana L.). Bul. Agron. 33(2): 16-22.

Hussain, M., M.A. Malik, M. Farooq, M.Y. Ashraf, M.A. Cheema. 2008. Improving drought tolerance by exogenous application of glycinebetaine and salicylic acid in sunflower. J. Agron Crop Sci. 194: 193-199.

Jaleel, C. A., R. Gopi, B. Sankar, M. Gomathinayagam, R. Panneerselvam. 2008. Differential responses in water use efficiency in two varieties of Catharanthus roseus under drought stress. Comptes Rendus Biologies. 331(1): 42-47.

Jaleel, C.A., P. Manivannan, A. Wahid, M. Farooq, H.J. Al-Juburi, R. Somasundaram, R. Panneerselvam. 2009. Drought Stress in Plants: A Review on Morphological Characteristics and Pigments Composition. Int. J. Agric. Biol. 11(1): 100-105.
Jin, J., H. Cui, X. Lv, Y. Yang, Y. Wang, W. Lu. 2016. Exogenous $\mathrm{CaCl}_{2}$ reduces salt stress in sour jujube by reducing $\mathrm{Na}^{+}$and increasing $\mathrm{K}^{+}, \mathrm{Ca}^{2+}$, and $\mathrm{Mg}^{2+}$ in different plant organs. J. Hort. Sci. Biotech. 1-9.

Kader, M.A., S. Lindberg. 2010. Cytosolic calcium and $\mathrm{pH}$ signaling in plants under salinity stress. Plant Signaling \& Behavior. 5(3): 233-238.

Khodarahmpour, Z. 2011. Effect of drought stress induced by polyethylene glycol (PEG) on germination indices in corn (Zea mays L.) hybrids. Afr. J. Biotechnol. 10(79): 18222-18227.

Kong, L., S.M. Attree, L.C Fowke. 1998. Effect of polyethylene glycol and methylglyoxal bis (guanylhydrazone) on endogenous polyamine levels and somatic embryo maturation in white spruce (Picea glauca). Plant Sci. 133:211-220.

Kramer, P.J., J.S. Boyer. 1995. Water Relations of Palnts and Soils. California (USA): Academic Press.

Kumar, R.R., K. Krishna, G.R. Naik. 2011. Effect of polyethylene glycol induced water stress on physiological and biochemical responses in pigeonpea (Cajanus cajan L. Millsp.). Rec Res Sci Tech. 3(1): 148-152.

Lee, B.R., Y.L. Jin, W. J. Jung, J. C. Avice,A. Morvan-Bertrand, A. Ourry, T. H. Kim. 2008. Water-deficit accumulates sugars by starch degradation-not by de novo synthesis-in white clover leaves (Trifolium repens). Physiologia Plantarum. 134(3): 403-411.

Mahmood, M., S.S. Bidabadi, C. Ghobadi, D. J. Gray. 2012. Effect of methyl jasmonate treatments on alleviation of polyethylene glycol- mediated water stress in banana (Musa acuminata cv. "Berangan", AAA) shoot tip cultures. Plant Growth Regulation. 68(2): 161-169. 
Marcinska, I., C. Ilona, S. Edyta, F. Maria, G. Stanislaw, T. J. Maciej, J. Franciszek, H. Tomasz, D, Michal, D. Kinga, N. Agata, A. Q. Steve. 2013. Impact of osmotic stress on physiological and biochemical characteristics in drought-susceptible and drought-resistant wheat genotypes. Acta Physiologiae Plantarum. 35: 451-461.

Mexal, J., J.T. Fisher, J. Osteryoung, C.P. Patrick. 1975. Oxygen availability in polyethylene glycol solutions and its implication in plant water relations. Plant Physiol. 55:20-24.

Miransari, M. 2010. Contribution of arbuscular mycorrhizal symbiosis to plant growth under different types of soil stress. Plant Biology. 12(4):563-569.

Misra, N., A. K. Gupta. 2005. Effect of salt stress on proline metabolism in two high yielding genotypes of green gram. Plant Sci. 169: 331-339.

Morgan, S.H., P.J. Maity, C. Geilfus, S. Linberg, K.H. Muhling. 2014. Leaf ion homeostasis and plasma membrane $\mathrm{H}^{+}$ATPase activity in Vicia faba change after extra calcium and potassium supply under salinity. Plant Physiol. and Biochem. 82: 244-253.

Mustaha, M.A. 2012. Pemacuan pertumbuhan bibit manggis (Garcinia mangostana L.) dengan rekayasa media tumbuh. Disertasi. Institut Pertanian Bogor. Bogor.

Nawaz, R., R. Ahmad, E.A. Waraich, M.S. Naeem, R.N. Shabbir. 2012. Nutrient uptake, physiological responses, and yield attributes of wheat (Triticum aestivum L.) exposed to early and late drought stress. Journal of Plant Nutrition. 35(6): 961-974.

Parida, A. K., B. Jha. 2012. Physiological and biochemical responses reveal the drought tolerance efficacy of the halophyte Salicornia brachiate. J Plant Growth Regul. 32(2): 342-352.
Patanè, C. 2010. Leaf area index, leaf transpiration and stomatal conductance as affected by soil water deficit and vpd in processing tomato in semi arid mediterranean climate. J. Agronomy and Crop Science. 197(3): 165-176.

Peaucelle, A., S. Braybrook, H. Höfte. 2012. Cell wall mechanics and growth control in plants: the role of pectins revisited. Front Plant Sci. 3: 121.

Ranganayakulu, G.S., G.Veeranagamallaiah, C. Sudhakar. 2013. Effect of salt stress on osmolyte accumulation in two groundnut cultivars (Arachis hypogaea L.) with contrasting salt tolerance. Afr. J. Plant Sci. 12:5 86-592.

Rouphael, Y., M. Cardarelli, D. Schwarz, P. Franken, G. Colla. 2012. Effects of Drought on Nutrient Uptake and Assimilation in Vegetable Crops. Plant Responses to Drought Stress. 171-195.

Sapre, S. S., D. N. Vakharia. 2017. Silicon induced physiological and biochemical changes under polyethylene glycol-6000 water deficit stress in wheat seedlings. Journal of Environmental Biology. 38(2): 313-319.

Songsri, P., S. Jogloy, C.C. Holbrook, T. Kesmala, N. Vorasoot, C. Akkasaeng, A. Patanothai. 2009. Association of root, specific leaf area and SPAD chlorophyll meter reading to water use efficiency of peanut under different available soil water. Agricultural Water Management. 96(5): 790-798.

Sopandie, D. 2014. Fisiologi Adaptasi Tanaman terhadap Cekaman Abiotik pada Agroekosistem Tropika. IPB Press. Bogor.

Swasono, D.H. 2012. Karakteristik fisiologi toleransi tanaman bawang merah terhadap cekaman kekeringan di tanah pasir pantai. Jurnal AgriSains. 3(4): 1-16.

Taiz, L., E. Zeiger. 2012. Plant Physiologi Online. Fifth edition. Sinauer Associates. 
Van der Weele, C.M., W.G. Spollen, R.E. Sharp, T.I. Baskin. 2000. Growth of Arabidopsis thaliana seedlings under water deficit studied by control of water potential in nutrient-agar media. Journal of Experimental Botany. 51(350): 15551562.

Verslues, P.E., A.B. Elizabeth. 2004. LWRI and $L W R 2$ are required for osmoregulation and osmotic adjustment in Arabidopsis. Environmental Stress and Adaptation. 136(1): 2831-2842.

Wani, S.H., N.B. Singh, A. Haribhushan, J.I. MirI. 2013. Compatible solute engineering in plants for abiotic stress tolerance-role of glycine betaine. Curr. Genomics. 14: 157-165.

Waraich, E.A., R. Ahmad, Saifullah, M.Y. Ashraf, Ehsanullah. 2011. Role of mineral nutrition in alleviation of drought stress in plants. Aust. J. Crop Sci. 5:764-777.

Wu, F., W. Bao, F. Li, N. Wu. 2007. Effect of drought stress and $\mathrm{N}$ supply on the growth, biomass partitioning and wateruse efficiency of Sophora davidii seedlings. Environ. Experiment. Bot. 63:248-255.

Wu, H., M. Zhu, L. Shabala, M. Zhou, S. Shabala. 2014. K+retention in leaf mesophyll, an overlooked component of salinity tolerance mechanism: A case study for barley. Journal of Integrative Plant Biology. 57(2): 171-185.

Zhang, W., Z. Cao, Z. Xie, D. Lang, L. Zhou, Y. Chu, Q. Zhao, X. Zhang, Y. Zhao. 2017. Effect of water stress on roots biomass and secondary metabolites in the medicinal plant Stellaria dichotoma L. Scientia Horticulturae. 224: 280-285. 